\title{
Cellular Mechanisms of Somatostatin Action in the Gut
}

\author{
John DelValle, Jung Park, Tsutomu Chiba, and Tadataka Yamada
}

\begin{abstract}
We have used isolated canine parietal cells to examine the receptor and postreceptor events mediating the inhibitory effects of somatostatin on acid secretion. Somatostatin-14 (S14) and somatostatin-28 (S28) dose dependently inhibited parietal cells stimulated by secretagogues that activate both the adenylate cyclase/cyclic adenosine monophosphate and the inositol phospholipld/ protein kinase $\mathrm{C}$ cascades. The inhibitory action was mediated via a specific cell surface receptor that consists of a single subunit protein (molecular weight $\mathbf{9 9 , 0 0 0}$ d). This receptor recognized $\mathbf{S 1 4}$ and $\mathbf{5 2 8}$ equally well. Somatostatin inhibited parietal cell activity via mechanisms that are both dependent on and independent of a pertussis toxin-sensitive inhibitory guanine nucleotide binding protein.
\end{abstract}

(c) 1990 by W.B. Saunders Company.

QINCE ITS initial isolation from sheep hypothalamus,' somatostatin has been found in many areas throughout the body including the gastric mucosa. ${ }^{2}$ Both in vivo and in vitro studies have demonstrated that somatostatin is released into the circulation in response to nutrient ingestion, ${ }^{3}$ reaching plasma concentrations that are sufficient to inhibit gastric acid secretion. ${ }^{4}$ In addition, somatostatin containing D-cells, which are found throughout the fundic mucosa, contain long cytoplasmic processes ${ }^{5}$ extending to parietal cells, suggesting a local or paracrine regulatory role for this peptide on acid secretory cell function. Despite the abundance of in vitro and in vivo studies examining the effect of somatostatin on acid secretion, its direct action on parietal cell function continues to be a source of debate. The present studies demonstrate our efforts to elucidate the receptor and postreceptor events important in mediating somatostatin's regulatory action on parietal cells.

\section{MATERIALS AND METHODS}

\section{Reagents}

Somatostatin-14 (S14), somatostatin-28 (S28), [Leu ${ }^{8}-\mathrm{D}-\mathrm{Trp}^{22}$ $\mathrm{Tyr}^{25} \mathrm{jS} 28$ (S28-A), and pentagastrin were purchased from Peninsula Laboratories (Belmont, $\mathrm{CA}) . \mathrm{Na}^{125} \mathrm{I},\left[{ }^{14} \mathrm{C}\right]$ aminopyrine $(80 \mu \mathrm{Ci}$ / nmol), myo- $\left[2-{ }^{3} \mathrm{H}\right]$ inositol $(15.8 \mathrm{Ci} / \mathrm{mmol})$, and $\left[{ }^{32} \mathrm{P}\right]$ orthophosphoric acid (carrier free) were obtained from DuPont-New England Nuclear (Boston, MA). Cyclic adenosine monophosphate (cAMP) assay kits, $\left[\alpha{ }^{32} \mathrm{P}\right]$ adenosine triphosphate (ATP) $(10$ to $15 \mathrm{Ci} / \mathrm{mmol})$, tissue solubilizer (NCS), and aqueous scintillation cocktail (ACS) were from Amersham (Arlington Heights, IL). Earle's balanced salt solution (EBSS) and Ham's F-12/Dulbecco's modified Eagle's (50:50) medium

From the Department of Internal Medicine, The University of Michigan Medical Center, Ann Arbor, MI and the Third Department of Internal Medicine, Kobe University School of Medicine, Kobe, Japan.

Supported by National Institutes of Health Grant No. ROI DK33500 and funds from the Michigan Gastrointestinal Peptide Research Center under NIII Grant No. P30-DK34933.

Dr. DelValle is a recipient of a Robert Wood Johnson Minority Faculty Development Award and an NIH Clinical Investigator Award (NIH grant KO8-DK01823).

Address reprint requests to John DelValle, MD, 3912 Taubman Center, Box 0362, Division of Gastroenterology, The University of Michigan Medical Center, Ann Arbor, MI 48109-0362.

(C) 1990 by W.B. Saunders Company.

0026-0495/90/3909-2036\$03.00/0
(HF-12/DMEM) were obtained from Irvine Scientific (Santa Ana, CA). All other chemicals were from Sigma (St Louis, MO).

\section{Cell Preparation}

Canine parietal cells were isolated and enriched using a modification of the technique previously described by Soll. ${ }^{6}$ Freshly obtained canine fundic mucosa was thinly sliced and exposed serially to incubations with collagenase $(0.35 \mathrm{mg} / \mathrm{mL})$ and EDTA ( $1 \mathrm{mmol} / \mathrm{L})$. Parietal cells were enriched to greater than $95 \%$ homogeneity using counterflow elutriation followed by density gradient centrifugation ( $50 \%$ percoll) of the acutely dispersed cells. ${ }^{7}$ The uptake of $\left[{ }^{14} \mathrm{C}\right]$ aminopyrine was used as a measure of parietal cell acid secretory activity. ${ }^{8}$ Enriched parietal cells $\left(2 \times 10^{6}\right.$ cells $\left./ \mathrm{mL}\right)$ were incubated with $0.1 \mu \mathrm{Ci}$ of $\left[{ }^{14} \mathrm{C}\right]$ aminopyrine and the reagents to be tested for 20 minutes. Cells were then pelleted, solubilized in NCS, and counts were determined in a liquid scintillation counter after adding ACS.

\section{Receptor Binding Studies}

The somatostatin ligand S28-A was labeled with $\mathrm{Na}^{125}$ I using chloramine-T and purified by gel filtration. ${ }^{9}$ The specific activity of the ligand obtained was $2,000 \mathrm{Ci} / \mathrm{mmol}$. Binding studies with parietal cells were performed as previously described. ${ }^{9}$ For receptor crosslinking, ${ }^{125} \mathrm{I}$-S28-A was incubated either with intact cells for 1 hour at $37^{\circ} \mathrm{C}$ or with membranes for 2 hours at $25^{\circ} \mathrm{C}$ and then in 500 $\mu \mathrm{mol} / \mathrm{L}$ disuccinimidyl suberate for 15 minutes at $0^{\circ} \mathrm{C}$. After solubilization in $62.5 \mathrm{mmol} / \mathrm{L}$ Tris buffer (pH 6.8) containing $2 \%$ sodium dodecyl sulfate (SDS), the preparations were applied to SDS polyacrylamide gel electrophoresis and the gels were examined by autoradiography.

\section{Signal Transduction Studies}

After incubating parietal cells $\left(2 \times 10^{6}\right.$ cells $\left./ \mathrm{mL}\right)$ with various reagents for 15 minutes in EBSS at $37^{\circ} \mathrm{C}$, the reaction was terminated by adding ice chilled trichloroacetic acid for 15 minutes. Following centrifugation of the reaction mixture and ether extraction of the supernatant, CAMP was quantified by a protein binding assay ${ }^{10}$ using a commercially available kit. Mobilization of membrane inosito phospholipids in parietal cell membranes was determined using previously described methods. ${ }^{11-14}$ Membrane-associated protein kinase $C$ activity was measured in parietal cells treated with various secretagogues using methods previously described by Kikkawa et al. ${ }^{i 5}$ For measurement of cytosolic calcium [ $\left.\mathrm{Ca}^{2+}\right]$ i, purified parietal cells were loaded with Fura- $2 \mathrm{AM}(1 \mu \mathrm{mol} / \mathrm{L})$ then attached to a cell-tak coated coverslip placed in a flow through chamber; fluorescence ( 340 and $380 \mathrm{~nm}$ ) was measured in a single parietal cell using a Nikon Diaphot inverted microscope (Garden City, NY) coupled to a Spex (DM 3,000$\mathrm{cm}$ ) spectrofluorometric system (Edison, NJ). Parietal cell auto fluorescence was subtracted from each experiment and $\left[\mathrm{Ca}^{2+}\right] \mathrm{i}$ calibration was performed using digitonin $(75 \mu \mathrm{mol} / \mathrm{L})$ and EGTA $(4 \mathrm{mmol} /$ 
L). $\left[\mathrm{Ca}^{2+}\right] \mathrm{i}$ was calculated using the equation developed by Grynkiewicz et al. ${ }^{16}$

\section{RESULTS AND DISCUSSION}

As shown in Fig 1, both S14 and S28 inhibited pentagastrin plus isobutyl methylxanthine (IMX)-stimulated parietal cell activity in a dose-dependent fashion. Similar inhibitory results were obtained when parietal cells were stimulated with either carbachol, histamine, forskolin, or dibutyryl cAMP. Correlation of somatostatin's biological activity with binding to a specific cell surface receptor required radioligand studies using ${ }^{125}$ I S-28A. ${ }^{125}$ I S-28A bound to isolated enriched parietal cells in a specific and time-dependent fashion. Binding inhibition studies performed with both $\mathrm{S} 28$ and $\mathrm{S} 14$ showed almost superimposable displacement of bound radioligand in a dose-dependent manner, with half maximal inhibition occurring at concentrations of $6.2 \pm 1.3 \times 10^{-9} \mathrm{~mol} / \mathrm{L}$ (n $=6)$ and $9.4 \pm 2.2 \times 10^{-9} \mathrm{~mol} / \mathrm{L}(\mathrm{n}=6)$ for $\mathrm{S14}$ and $\mathrm{S} 28$, respectively (Fig 2). Evaluation of the somatostatin binding data through Scatchard analysis showed the presence of both high-affinity $\left(K_{d}=3.2 \times 10^{-9} \mathrm{~mol} / \mathrm{L}\right)$ and low-affinity $\left(K_{d}\right.$ $\left.=2.1 \times 10^{-7} \mathrm{~mol} / \mathrm{L}\right)$ binding sites on parietal cells. Of note is the close correlation between the $K_{d}$ of the high-affinity receptor $\left(9.2 \pm 2.2 \times 10^{-9} \mathrm{~mol} / \mathrm{L}\right)$ and the concentrations of S28 and S14 required for half maximal inhibition of acid secretion (Fig 1). These data confirm the presence of a functional somatostatin receptor on parietal cells. Our studies indicate that this receptor recognizes $\mathrm{S} 14$ and $\mathrm{S} 28$ equally well, unlike somatostatin receptors in other cell systems. ${ }^{17,18}$

In an attempt to characterize the somatostatin receptor biochemically, ${ }^{125}$ I S-28A was crosslinked via disuccinimidyl

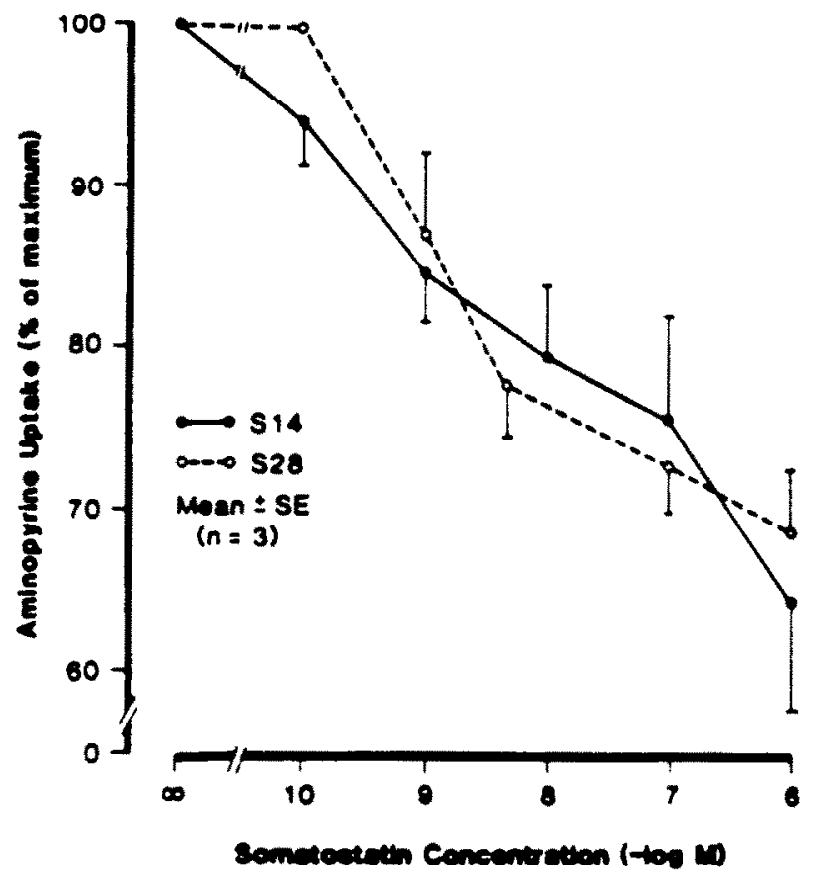

Fig 1. S14- and $\$ 28$-mediated inhibition of pentagastrin $\left(10^{-7}\right.$ $\mathrm{mol} / \mathrm{L})$ and $I M X\left(10^{-4} \mathrm{~mol} / \mathrm{L}\right)$-stimulated aminopyrine uptake in isolated parietal cells.

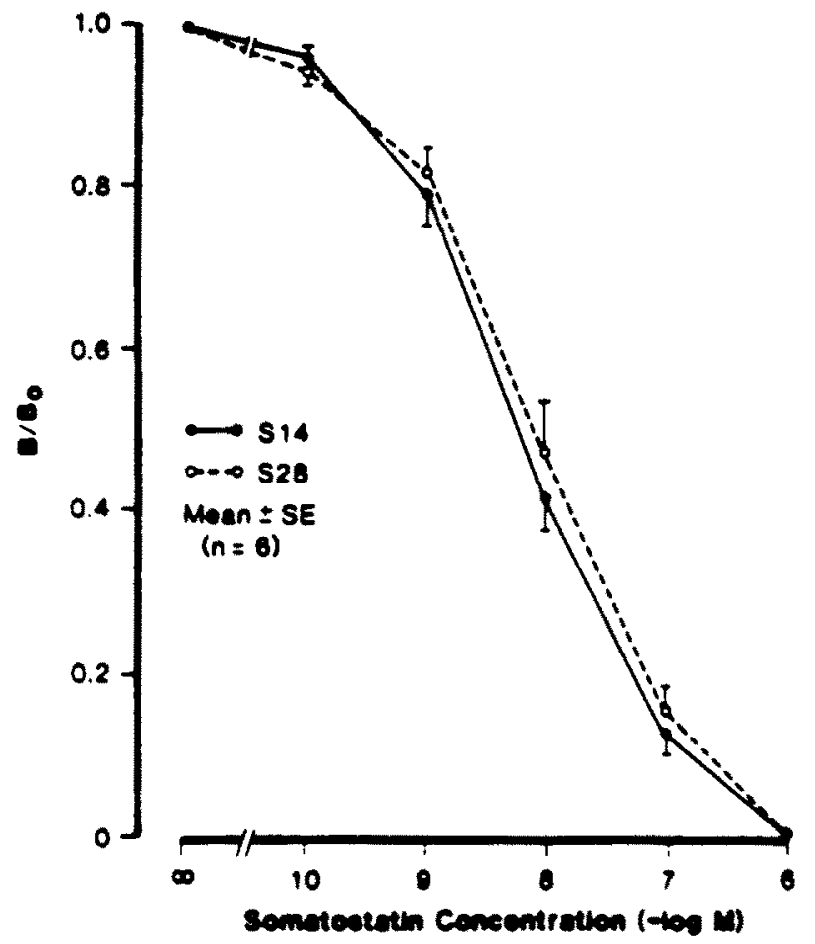

Fig 2. Inhibition of ${ }^{128}$-[Leu" $\left.-D-T^{42}-p^{22} y^{25}\right] S 28$ binding to gastric parietal celis by S14 and S28. Results are expressed as a percentage of binding in the absence of unlabeled peptides $(\mathrm{B} / \mathrm{Bo})$.

suberate to both intact cells and membranes obtained from purified parietal cells. A single band of specific crosslinking with a molecular weight of $102 \mathrm{kd}$ was obtained. Both S14 and $\mathbf{S 2 8}$ competitively inhibited crosslinking in a dose-dependent fashion with $50 \%$ inhibition occurring at $10^{-7}$ to $10^{-8} \mathrm{~mol} / \mathrm{L}$ for both peptides. The pattern and kinetics of crosslinking was not altered by increased parietal cell purity but the amount of nonspecific labeling was reduced substan-

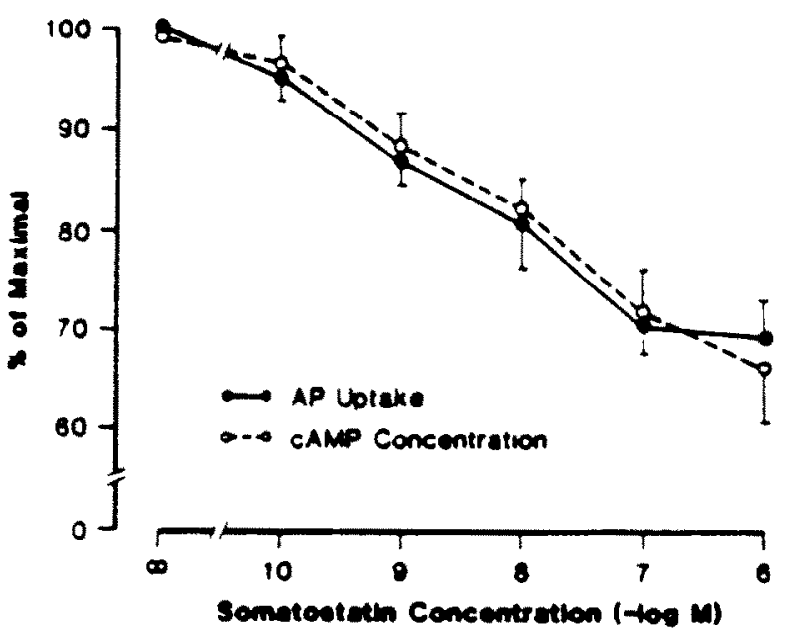

Fig 3. Effect of somatostatin on parietal cell [ $\left.{ }^{44} \mathrm{C}\right]$ aminopyrine uptake and cAMP production induced by histamine $\left(10^{-*} \mathrm{~mol} / \mathrm{L}\right)$ plus IMX $\left(10^{-4} \mathrm{~mol} / \mathrm{L}\right)$. 
Table 1. Effects of Acid Secretagogues on $\left[{ }^{14} \mathrm{C}\right]$ Aminopyrine Uptake and cAMP Production in, Release of $\left[{ }^{3} \mathrm{H}\right]$ Inositol Trisphosphate

$\left({ }^{3} \mathrm{H}-\mathrm{IP}_{3}\right)$ from, and ${ }^{32} \mathrm{P}$-Labeling of Phosphatidic Acid, Phosphatidyl Inositol, and Phosphatidyl Inositol Bisphosphate in Parietal Cells

\begin{tabular}{lcccccc}
\hline \multicolumn{1}{c}{ Stimulant } & $\begin{array}{c}\text { AP-uptake } \\
(n=4)\end{array}$ & $\begin{array}{c}\text { cAMP } \\
(n=5)\end{array}$ & $\begin{array}{c}{ }^{3} \text { H-IP } \\
(n=6)\end{array}$ & $\begin{array}{c}\text { PA } \\
(n=6)\end{array}$ & $\begin{array}{c}\text { Pf } \\
(n=6)\end{array}$ & $\begin{array}{c}\text { PIP } \\
(n=6)\end{array}$ \\
\hline Histamine $\left(10^{-4} \mathrm{~mol} / \mathrm{L}\right)$ & $508 \pm 46 \dagger$ & $163 \pm 11 \dagger$ & $108 \pm 5$ & $106 \pm 4$ & $110 \pm 12$ & $97 \pm 4$ \\
Forskolin $\left(10^{-4} \mathrm{~mol} / \mathrm{L}\right)$ & $1,414 \pm 114$ & $517 \pm 47 \dagger$ & $101 \pm 8$ & $105 \pm 3$ & $109 \pm 10$ & $99 \pm 5$ \\
dbcAMP $\left(10^{-3} \mathrm{~mol} / \mathrm{L}\right)$ & $1,300 \pm 216 \dagger$ & $\mathrm{NT}$ & $103 \pm 6$ & $98 \pm 4$ & $106 \pm 7$ & $100 \pm 4$ \\
Carbachol $\left(10^{-4} \mathrm{~mol} / \mathrm{L}\right)$ & $1,499 \pm 187 \dagger$ & $103 \pm 15$ & $265 \pm 18 \dagger$ & $173 \pm 17 \dagger$ & $333 \pm 12 \dagger$ & $73 \pm 5 \dagger$ \\
Pentagastrin $\left(10^{-7} \mathrm{~mol} / \mathrm{L}\right)$ & $421 \pm 64 \dagger$ & $96 \pm 14$ & $192 \pm 14 \dagger$ & $143 \pm 26 \dagger$ & $205 \pm 14 \dagger$ & $79 \pm 5 *$ \\
\hline
\end{tabular}

NOTE. Data are expressed as means \pm SE percent of unstimulated control values.

Abbreviations: AP, aminopyrine; ${ }^{3} \mathrm{H}-\mathrm{PP}_{3},\left[{ }^{3} \mathrm{H}\right]$ (tritiated) inositol trisphosphate; NT, not tested; PA, phosphatidic acid; PI, phosphatidyl inositol; PIP, phosphatidyl inositol bisphosphate

" $P<.05 v$ control

$\uparrow P<.01 \vee$ control.

tially. In addition, the size of the crosslinked band was not altered by treatment of preparations with dithiotreitol in concentrations as large as $100 \mathrm{mmol} / \mathrm{L}$. These data suggest that the parietal cell somatostatin receptor is a single subunit protein with a molecular weight of 99,000 (after subtracting the molecular weight of S-28A).

We next examined the intracellular mechanisms responsible for somatostatin's inhibitory effects on acid secretion. Somatostatin dose dependently inhibited aminopyrine uptake and CAMP accumulation in parietal cells in a parallel fashion (Fig 3). Pretreatment of parietal cells with pertussis toxin $(100 \mathrm{ng} / \mathrm{mL}$ ) reversed the inhibitory effect of somatostatin on forskolin- and histamine-mediated acid secretion but did not alter somatostatin's inhibitory action on dibutyryl cAMP and pentagastrin-mediated aminopyrine accumulation. Additional experiments showed that somatostatin's inhibitory action on CAMP accumulation induced by histamine and forskolin was also reversed by pertussis toxin pretreatment. These data are consistent with the notion that, in addition to inhibiting adenylate cyclase via a pertussis toxin-sensitive guanine nucleotide binding protein, somatostatin may exert its action on target cells at a point distal to the production of cAMP.

Previous studies have demonstrated that both gastrin and carbachol stimulate parietal cells through a membrane ino-

\begin{tabular}{lc}
$\begin{array}{c}\text { Table 2. Effects of Acid Secretagogues on Membrane- } \\
\text { Associated Protein Kinase C Activity in Parietal Colls }\end{array}$ \\
\hline \multicolumn{1}{c}{ Condition } & $\begin{array}{c}\text { Protein Kinase C Activity } \\
\text { (pmol }{ }^{32} \mathrm{P} / \mathrm{min} \cdot \mathrm{mg} \text { Protein) }\end{array}$ \\
\hline Control & $70.6 \pm 6.3$ \\
Histamine $\left(10^{-4} \mathrm{~mol} / \mathrm{L}\right)$ & $71.5 \pm 6.5$ \\
dbcAMP $\left(10^{-3} \mathrm{~mol} / \mathrm{L}\right)$ & $68.4 \pm 5.8$ \\
Carbachol $\left(10^{-4} \mathrm{~mol} / \mathrm{L}\right)$ & $122.5 \pm 6.5^{*}$ \\
PG $\left(10^{-3} \mathrm{~mol} / \mathrm{L}\right)$ & $112.9 \pm 6.2^{*}$ \\
TPA $\left(10^{-7} \mathrm{~mol} / \mathrm{L}\right)$ & $132.2 \pm 11.0^{*}$
\end{tabular}

NOTE. Data are expressed as means $\pm \operatorname{SEM}(n=6)$.

Abbreviations: PG, pentagastrin; TPA, tetradecanoyl-phorbol-13-acetate.

- $P<.01$ v control. sitol phospholipid/protein kinase C-dependent pathway. As shown in Tables 1 and 2 , although somatostatin inhibited both pentagastrin and carbachol-mediated stimulation of aminopyrine uptake in a dose-dependent manner, it had no effect either on the turnover of membrane inositol phospholipids or on the activation of protein kinase $C$ induced by these two agents. These results suggest that somatostatin's inhibitory effect on parietal cells occurs at a distal point in the signal transduction cascade activated by gastrin and carbachol.

Previous investigators have demonstrated an effect of somatostatin on regulating $\left[\mathrm{Ca}^{2+}\right] \mathrm{i}$ in various cell types. ${ }^{19.20} \mathrm{Ac}-$ cordingly, we examined the effect of somatostatin on carbachol and gastrin-mediated increases in $\left[\mathrm{Ca}^{2+}\right] \mathrm{i}$ in parietal cells and observed that maximum concentrations of somatostatin $\left(10^{-6} \mathrm{~mol} / \mathrm{L}\right)$ failed to alter resting $\left[\mathrm{Ca}^{2+}\right] \mathrm{i}$ or the initial transient increase in $\left[\mathrm{Ca}^{2+}\right]$ i stimulated by maximal effective doses of carbachol or gastrin. Preliminary studies also suggest that somatostatin has no effect on the sustained rise in $\left[\mathrm{Ca}^{2+}\right]$ stimulated by both carbachol and gastrin.

To conclude, our studies demonstrate that somatostatin is capable of inhibiting parietal cell activity stimulated by secretagogues that activate both adenylate cyclase and membrane inositol phospholipid turnover in a direct manner via a specific cell surface receptor. Part of its inhibitory action is mediated via a pertussis toxin-sensitive guanine nucleotide binding protein, but a component of its inhibitory action is insensitive to pertussis toxin and appears to occur at a distal site in various signal transduction cascades where stimulatory events converge to induce cell activation. This notion is supported by the observations that somatostatin may induce protein dephosphorylation ${ }^{21}$ or inhibit exocytosis. ${ }^{22}$ Somatostatin's inhibitory action may occur even at the level of the nucleus. We have demonstrated recently that somatostatin is capable of inhibiting carbachol-mediated stimulation of carbonic anhydrase II and actin gene expression, elements that are important in the regulation of parietal cell activity.

\section{ACKNOWLEDGMENT}

We are grateful to Pamela Evans for typing this manuscript. 


\section{REFERENCES}

1. Brazeau P, Vale W, Burgus R, et al: Hypothalamic polypeptide that inhibits the secretion of immunoreactive pituitary growth hormone. Science 179:77-79, 1973

2. Yamada T, Chiba T: Somatostatin, in Makhlouf G (ed): Handbook of Physiology, Section 6: The Gastrointestinal System, vol II: Neural and Endocrine Biology. Bethesda, MD, American Physiology Society, 1989, pp 431-454

3. Colturi T, Unger R, Feldman M: Role of circulating somatostatin in regulation of gastric acid secretion, gastrin release and islet cell function. Studies in healthy subjects and duodenal ulcer patients. J Clin Invest 74:417-423, 1984

4. Seal A, Yamada T, Debas H, et al: Somatostatin- 14 and -28 clearance and potency on gastric function in dogs. Am J Physiol 243: G97-G102, 1982

5. Larsson L-I, Goltermann N, De Magistris L, et al: Somatostatin cell processes as pathways for paracrine secretion. Science 205:13931395, 1979

6. Soll AH: The actions of secretagogues on oxygen uptake by isolated mammalian parietal cells. J Clin Invest 61:370-380, 1978

7. Campbell VW, DelValle J, Hawn M, et al: Carbonic anhydrasc II gene expression in isolated canine gastric parietal cells. Am J Physiol 256:G631-G636, 1989

8. Soll AH: Secretagogue stimulation of $\left[{ }^{14} \mathrm{C}\right]$ aminopyrine accumulation by isolated canine parietal cells. Am J Physiol 238:G336G375, 1980

9. Park J, Chiba T, Yamada T: Mechanisms for direct inhibition of canine gastric parietal cells by somatostatin. J Biol Chem 262: 14190-14196, 1987

10. Gilman AG: A protein binding assay for adenosine $3^{\prime}: 5^{\prime}$-cyclic monophosphate. Proc Natl Acad Sci USA 67:305-312, 1970

11. Berridge MJ, Dawson RMC, Downes CP, et al: Changes in the levels of inositol phosphates after agonist dependent hydrolysis of membrane phosphoinositides. Biochem J 212:473-482, 1983

12. Fisher SK, Figueiredo JC, Bartus RT: Differential stimulation of inositol phospholipid turnover in brain by analogs of oxotremorine. J Neurochem 43:1171-1179, 1984

13. Schacht J, Neale EA, Agranoff BW: Cholinergic stimulation of phospholipid labelling from $\left[{ }^{32} \mathrm{P}\right]$ orthophosphate in guinea-pig cortex synaptosomes in vitro: Subsynaptosomal localization. J Neurochem 23:211-218, 1974

14. Jolles J, Schrama LH, Gispen WH: Calcium dependent turnover of brain, polyphosphoinositides in vitro after prelabelling in vivo. Biochim Biophys Acta 666:90-98, 1981

15. Kikkawa Y, Minakuchi R, Takai T, et al: Calcium activated, phospholipid dependent protein kinase (protein kinase $\mathrm{C}$ ) from rat brain. Methods Enzymol 99:288-298, 1983

16. Grynkiewicz G, Poenie M, Tsien RY: A new generation of $\mathrm{Ca}^{2+}$ indicators with greatly improved fluorescence properties. J Biol Chem 260:3440-3450, 1985

17. Srikant $\mathrm{CB}$, Heisler S: Relationship between receptor binding and biopotency of somatostatin-14 and somatostatin-28 in mouse pituitary tumor cells. Endocrinology 117:271-278, 1985

18. Srikant CB, Patel YC: Somatostatin receptors on rat pancreatic acinar cells. Pharmacological and structural characterization and demonstration of down regulation in streptozotocin diabetes. J Biol Chem 261:7690-7696, 1986

19. Bicknell RJ, Schofield JG: Mechanism of action of somatostatin: Inhibiting ionophore A23187-induced release of growth hormone from dispersed bovine pituitary cells. FEBS Lett 68:23-26, 1976

20. Richardson UI: Adrenocorticotropin secretion by mouse pituitary tumor cells in culture: The role of $\mathrm{Ca}^{2+}$ in stimulated and somatostatin-inhibited secretion. Endocrinology 113:62-68, 1982

21. Reyl FJ, Lewin MJM: Intracellular receptor for somatostatin in gastric mucosal cells: Decomposition and reconstitution of somatostatin-stimulated phosphoprotein phosphotases. Proc Natl Acad Sci USA 79:978-982, 1982

22. Green R, Shields D: Somatostatin discriminates between the intracellular pathways of secretory and membrane proteins. $J$ Cell Biol 99:97-104, 1984 